\title{
The effect of dietary protein source and saponins on serum lipids and the excretion of bile acids and neutral sterols in rabbits
}

\author{
By CHITRA PATHIRANA, M. J. GIBNEY* AND T. G. TAYLOR \\ Department of Nutrition, School of Biochemical and Physiological Sciences, \\ University of Southampton
}

(Received 21 July 1980-Accepted 26 March 1981)

\begin{abstract}
1. Four groups of six rabbits were given purified diets in which the dietary variables were protein source (isolated soya-bean protein or cow's-milk protein) with or without saponin supplementation $(10 \mathrm{~g} / \mathrm{kg})$.

2. Rabbits given soya-based diets showed significantly lower serum concentrations of triglyceride and cholesterol $(P<0.01)$. The latter changes were confined to the cholesterol fractions of $\beta$-lipoproteins.

3. These changes in serum cholesterol were associated with a significantly increased excretion of acid and neutral sterols in animals given soya-bean protein.

4. There was no evidence to suggest that the effect of dietary protein source on serum lipids and the excretion of total and individual sterols was influenced by saponin supplementation.

5. These results do not support the hypothesis that the hypocholesterolaemia associated with plant proteins is due to the presence of saponins.
\end{abstract}

Although a specific effect of dietary protein on cholesterol metabolism has been known for some time (Meeker \& Kesten, 1940), little progress has been made in elucidating the mechanisms involved. Two main hypotheses have been proposed to explain the relative hypocholesterolaemic effect of plant proteins as opposed to animal proteins. Potter $e t$ al. (1979) have suggested that the hypocholesterolaemic effect of plant proteins, soya-bean proteins in particular, is a fortuitous result arising from the presence of saponins which have the capacity in vitro to adsorb bile acids to dietary fibre (Oakenfull \& Fenwick, 1978). A second hypothesis relates the hypocholesterolaemic effect of vegetable proteins to their amino acid composition per se (Kritchevsky, 1979). The purpose of the present study was to test the hypothesis that the hypocholesterolaemia associated with soya-bean-based diets is a function of the saponin fraction and to see whether supplementation of cow's-milk protein with saponin would reduce its hypercholesterolaemic action.

\section{EXPERIMENTAL}

Four groups of six weanling New Zealand white rabbits were used. Each group comprised four male and two female rabbits. The animals were housed individually in metabolism cages and had unrestricted access to fresh food and water. Each group was offered one of four diets for a period of $28 \mathrm{~d}$. The compositions of the basal diets are given in Table 1. A carbohydrate-free soya-tean protein isolate (Promine-D, Central Soya, Chicago, USA) was used. The metabolizable energy value of the diet was computed on the basis of 16.7, 16.7 and $37.7 \mathrm{~kJ} / \mathrm{g}$ carbohyd:rate, protein and fat respectively. Half the animals receiving each of the basal diets were given a dietary supplement of commercial white saponin $(10 \mathrm{~g} / \mathrm{kg}$; B.D.H. Ltd, Poole, Dorset). The rabbits were bled from the marginal ear vein on day 28 and the serum frozen at $-20^{\circ}$ for subsequent analysis. Faeces were collected during the last $7 \mathrm{~d}$ of the experimen.. The faeces were dried at $60^{\circ}$ in a forced-draught oven for at least $24 \mathrm{~h}$. Food intake and live-weight gain were recorded weekly.

- For reprints. 
Table 1. Compositions of the basal diets $(\mathrm{g} / \mathrm{kg})$

\begin{tabular}{|c|c|c|}
\hline \multirow[b]{2}{*}{ Ingredients } & \multicolumn{2}{|c|}{ Protein source } \\
\hline & $\begin{array}{l}\text { Cow's-milk } \\
\text { protein }\end{array}$ & $\begin{array}{c}\text { Isolated soya-bean } \\
\text { protein }\end{array}$ \\
\hline Promine D & - & $265 \cdot 15$ \\
\hline Dried skim milk & 416.5 & - \\
\hline Casein & $114 \cdot 3$ & - \\
\hline Bran & $119 \cdot 6$ & $119 \cdot 8$ \\
\hline Safflower oil & $3 \cdot 26$ & 4.79 \\
\hline Coconut oil & 4.88 & $7 \cdot 19$ \\
\hline Lactose & - & 222.0 \\
\hline Sucrose & $39 \cdot 5$ & $39 \cdot 2$ \\
\hline Starch & 276.5 & 274.4 \\
\hline Methionine & $1 \cdot 31$ & 4.9 \\
\hline Minerals* & 16.7 & $55 \cdot 1$ \\
\hline Vitamins $†$ & $7 \cdot 42$ & $7 \cdot 44$ \\
\hline
\end{tabular}

Chemical composition: metabolizable energy (MJ/kg), 14.6; energy from protein $(\%), 30$; energy from fat $(\%)$, 5 ; energy from carbohydrate $(\%), 65$; saponin supplementation $(\mathrm{g} / \mathrm{kg}), 0$ or 10.

* Final dietary concentration (/MJ): calcium $718 \mathrm{mg}$, phosphorus $642 \mathrm{mg}$, sodium $415 \mathrm{mg}$, potassium $800 \mathrm{mg}$, magnesium $117 \mathrm{mg}$, chloride $214 \mathrm{mg}$, iodine $270 \mu \mathrm{g}$, iron $15 \mathrm{mg}$, manganese $8 \mathrm{mg}$, zinc $9 \mathrm{mg}$, copper $975 \mu \mathrm{g}$, chromium $55 \mu \mathrm{g}$, molybdenum $97 \mu \mathrm{g}$, selenium $55 \mu \mathrm{g}$.

† Final dietary concentrations (/MJ): retinol $600 \mu \mathrm{g}$, cholecalciferol $120 \mu \mathrm{g}$, tocopherols $18 \mathrm{mg}$, choline chloride $103.53 \mathrm{mg}$, nicotinic acid $3.11 \mathrm{mg}$, calcium pantothenate $1.55 \mathrm{mg}$, pyridoxine hydrochloride $518 \mu \mathrm{g}$, menaphthone $210 \mu \mathrm{g}$, riboflavine $518 \mu \mathrm{g}$, thiamine hydrochloride $210 \mu \mathrm{g}$, biotin $15.5 \mu \mathrm{g}$, folic acid $155 \mu \mathrm{g}$, cyanocobalamin $2.06 \mu \mathrm{g}$, myo-inositol $104 \mu \mathrm{g}$.

\section{Analytical methods}

Serum was separated into total- and high-density-lipoprotein (HDL) fractions using the heparin-manganous chloride method of Warnick \& Albers (1978). The fractions were then assayed for cholesterol and triglyceride on a Technicon AutoAnalyzer model in using the Lieberman-Burchard reaction for cholesterol analysis and the method of Kessler \& Lederer (1965) for triglyceride assay. Faecal serols were extracted into acetone-ethanol $(1: 1)$ in a Soxhlet apparatus for $18 \mathrm{~h}$ and the sterols separated into acid and neutral fractions using the method of Wells \& Makita (1962). The acid sterols were methylated in a solution of diazomethane in diethyl ether filtered through charcoal, and the concentrations of individual neutral and acid sterols were then determined by gas-liquid chromatography. A Pye-Unicam 104 chromatogram was used. A $2 \mathrm{~m}$ column $(2 \mathrm{~mm}$ i.d.) was packed with $30 \mathrm{~g} \mathrm{OV}-1$ (Pye Unicam)/kg diatomite 100-200 mesh and maintained at a temperature of $270^{\circ}$. Nitrogen was used as the inert carrier gas at a flow-rate of $15 \mathrm{ml} / \mathrm{min}$. The sample injection chamber was maintained at $220^{\circ}$ while the detector (flame ionization) was kept at $300^{\circ}$. The internal standard for acid sterols was cholesterol acetate and for neutral sterols it was androstone-17 $\beta$-ol-3-one propionate. Individual peaks were identified using purified standards.

\section{Statistical analysis}

The results were analysed by analysis of variance and comparisons between means, following signficiant $F$ values, were compared using Tukey's test of significance (Steel \& Torrie, 1960). 
Table 2. Mean values for daily energy intake and live-weight gain expressed relative to final body-weight for rabbits given soya-bean protein or cow's-milk protein

(Mean values with their standard errors)

\begin{tabular}{|c|c|c|c|c|c|}
\hline \multirow{2}{*}{$\begin{array}{l}\text { Dietary saponin }(\mathrm{g} / \mathrm{kg}) \ldots \\
\text { Protein source... }\end{array}$} & \multicolumn{2}{|c|}{0} & \multicolumn{2}{|c|}{10} & \multirow[b]{2}{*}{ SEM } \\
\hline & $\begin{array}{l}\text { Soya- } \\
\text { bean }\end{array}$ & $\begin{array}{l}\text { Cow's } \\
\text { milk }\end{array}$ & $\begin{array}{l}\text { Soya- } \\
\text { bean }\end{array}$ & $\begin{array}{l}\text { Cow's } \\
\text { milk }\end{array}$ & \\
\hline $\begin{array}{l}\text { Energy intake } \\
(\mathrm{kJ} / \mathrm{kg} \text { live-we ght per } \mathrm{d})\end{array}$ & $0.35^{\mathrm{a}}$ & $0.41^{\mathrm{a}}$ & $0-47^{\mathrm{b}}$ & $0.47^{b}$ & 0.04 \\
\hline Live-weight gai $(\mathrm{g} / \mathrm{kg}$ per $\mathrm{d})$ & $9 \cdot 5$ & 7.8 & $8 \cdot 8$ & 9.9 & 0.8 \\
\hline
\end{tabular}

a.b Mean values with unlike superscripts letters were significantly different: $P<0.05$.

Table 3. Mean values for the effects of the four dietary treatments on serum total and high-density-lipoprotein ( $H D L)$ cholesterol and triglyceride ( $m$ mol/l) of rabbits given soya-bean protein or cow's-milk prctein

(Mean values with their standard errors)

\begin{tabular}{|c|c|c|c|c|c|}
\hline \multirow{2}{*}{$\begin{array}{l}\text { Dietary saponin }(\mathrm{g} / \mathrm{kg}) \ldots \\
\text { Protein source... }\end{array}$} & \multicolumn{2}{|c|}{0} & \multicolumn{2}{|c|}{10} & \multirow[b]{2}{*}{ SEM } \\
\hline & $\begin{array}{c}\text { Soya- } \\
\text { bean }\end{array}$ & $\begin{array}{l}\text { Cow's } \\
\text { milk }\end{array}$ & $\begin{array}{c}\text { Soya- } \\
\text { bean }\end{array}$ & $\begin{array}{l}\text { Cow's } \\
\text { milk }\end{array}$ & \\
\hline Serum total chciesterol: & $2 \cdot 55^{a}$ & $6 \cdot 22^{b}$ & $1 \cdot 75^{\mathrm{a}}$ & $5 \cdot 82^{b}$ & 0.5 \\
\hline HDL cholestirrol & 0.38 & 0.38 & 0.39 & 0.40 & 0.03 \\
\hline LDL + VLDI, cholesterol & $2 \cdot 17^{\mathrm{a}}$ & $5 \cdot 84^{b}$ & $1 \cdot 37^{2}$ & $5 \cdot 42^{b}$ & 0.4 \\
\hline Serum total triglycerides: & $0.75^{2}$ & $0.91^{\mathrm{b}}$ & $0.74^{a}$ & $0.89^{b}$ & 0.05 \\
\hline HDL triglycerides & 0.25 & 0.21 & 0.22 & 0.24 & 0.01 \\
\hline
\end{tabular}

LDL, low-density lipoprotein; VLDL, very low-density lipoprotein.

a,b Mean values with unlike superscript letters were significantly different: $P<0.05$.

\section{RESULTS}

Mean daily energy intake was significantly increased $(P<0.05)$ by saponin supplementation but was not reflected by changes in live-weight gain (Table 2). The dietary effects on serum lipids are given in Table 3. Rabbits fed on diets based on cow's-milk protein showed significantly higher total serum cholesterol and triglycerides and significantly morecholesterol in the very-low-density- and low-density-lipoprotein fraction $(P<0.005)$ than the rabbits given soya-bean protein. Dietary protein source did not influence HDL-cholesterol, and serum lipids were uninfluenced by the inclusion of the saponin. Furthermore, there was no evidence of an interactive effect of dietary protein source and saponin supplementation on serum lipids.

The dietary effects on the faecal excretion of total and individual acid sterols and neutral sterols are given in Tables 4 and 5 respectively. Animals given soya-bean protein excreted a significantly greater amount of both total acid and total neutral sterols $(P<0.05)$ than those given milk protein. Although saponin increased the excretion of both fractions, this effect was not statistically significant. Furthermore, although there was no statistical evidence of an interaction between saponin supplementation and dietary protein source on 


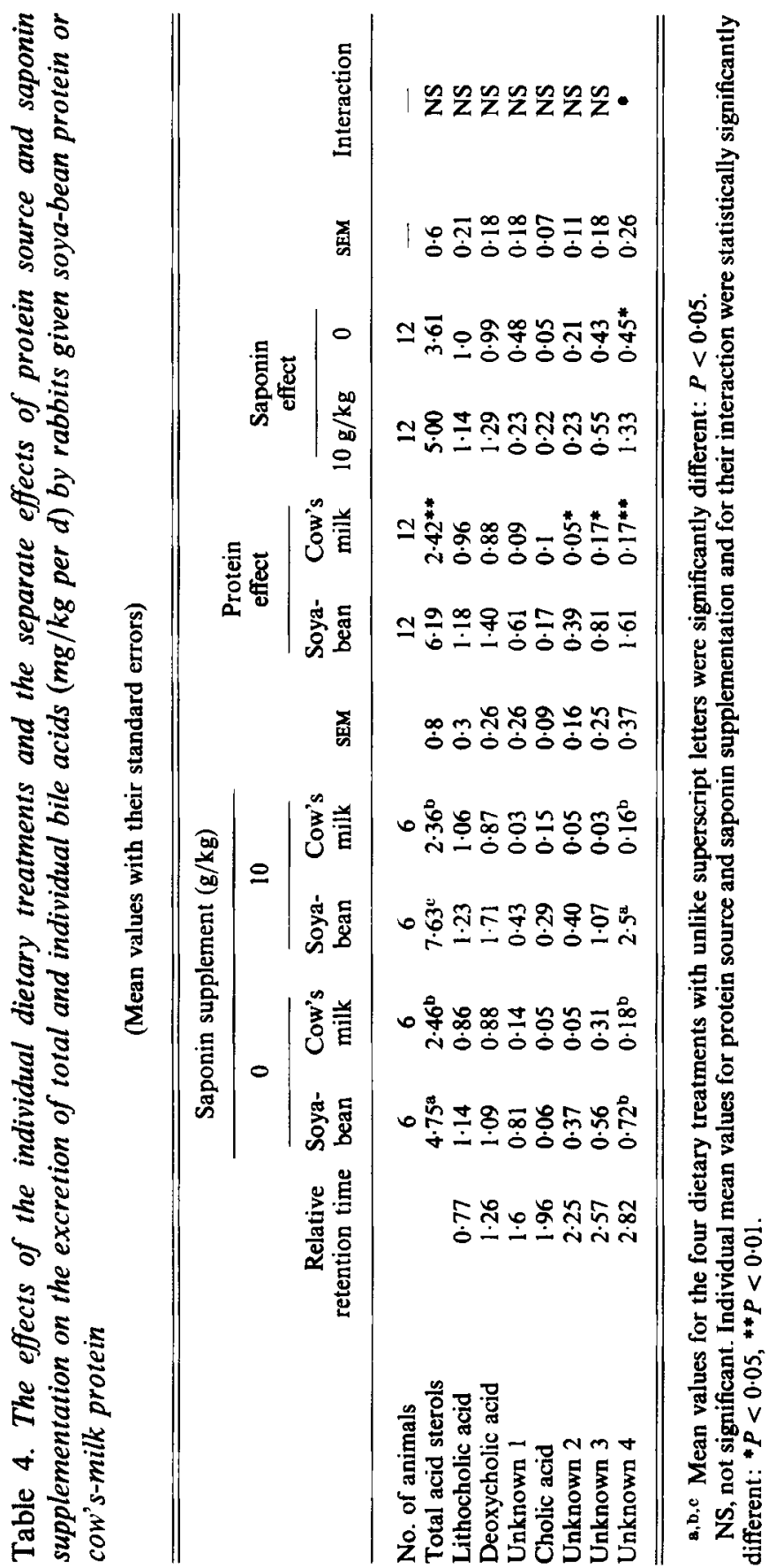




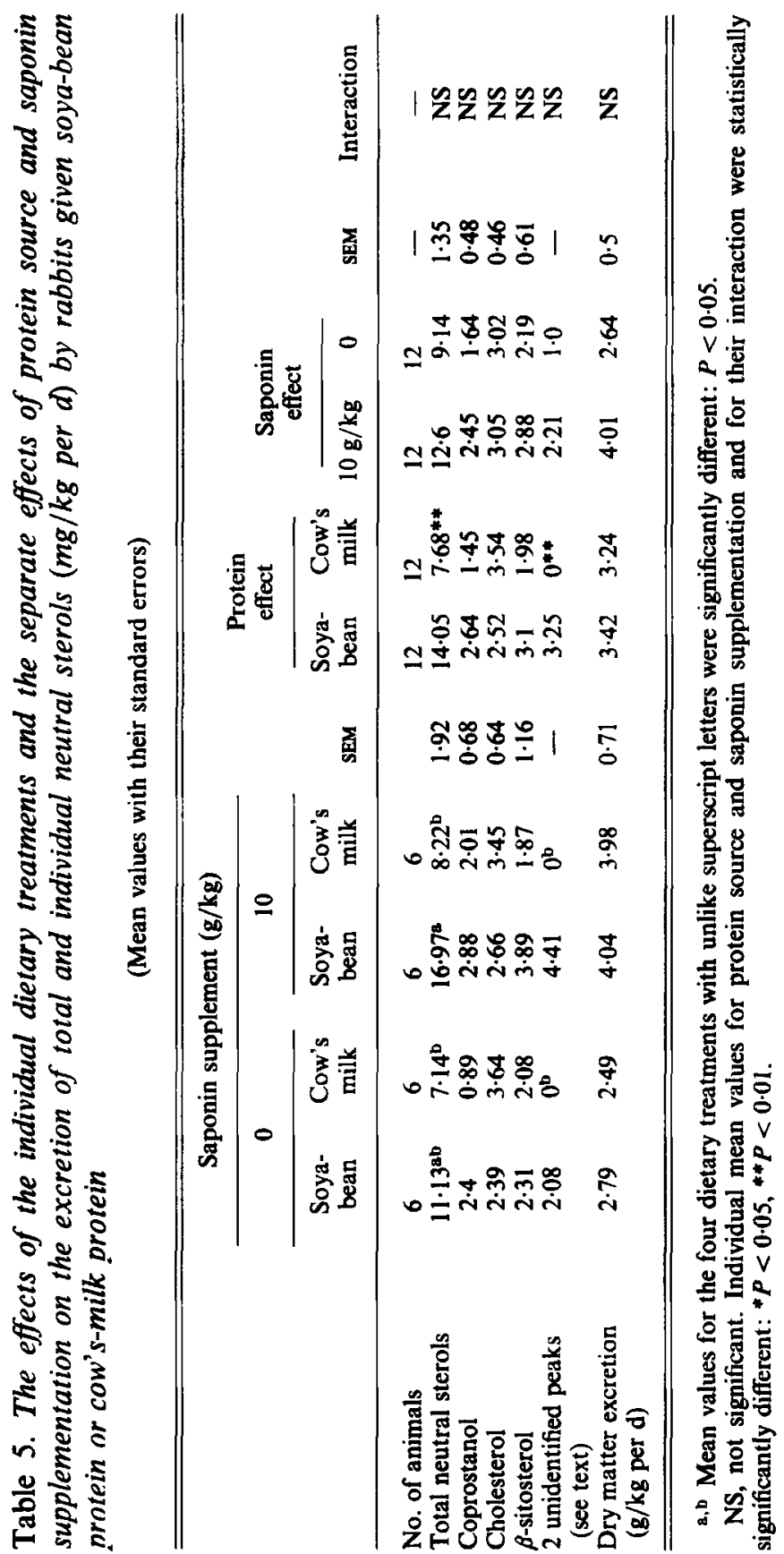


sterol excretion, saponin appeared to increase faecal sterols only when soya-bean protein was used. Thus the mean value for the excretion of total sterols increased from 15.9 to $24.6 \mathrm{mg} / \mathrm{kg}$ per $\mathrm{d}$ when saponin was added to the soya-bean-protein-based diet, whereas the corresponding change with milk-protein-fed rabbits was from 9.6 to $10.6 \mathrm{mg} / \mathrm{kg}$ per d.

There was no significant treatment effect on the excretions of any of the three major bile acids, cholic, lithocholic and deoxycholic acids. Four bile acids appearing on the gas-liquid chromatograph were not identified but probably were keto-or hydroxyketo-derivatives of deoxycholic acid (Danielson et al. 1963). Three of these unidentified bile acids with long relative retention times were excreted in significantly greater quantities by soya-bean-fed rabbits $(P<0.05)$. In one instance, that with the longest retention time, saponin caused a significant increase in its excretion, but only with rabbits given soya-bean protein $(P<0.05)$. Although total neutral sterol excretion was significantly increased by soyabean-protein feeding, there was no significant effect due to protein source on the excretion of cholesterol, coprostanol or $\beta$-sitosterol. Two peaks with long relative retention times were observed in considerable quantities in the chromatographs of all rabbits given soya-bean protein but were absent or present in only trace quantities in those of cow's-milk-protein-fed rabbits. The gas-liquid chromatographic results of Hellstrom et al. (1962) suggest that these sterols may have been keto-derivatives of cholesterol.

\section{DISCUSSION}

In an investigation of the hypocholesterolaemic action of dietary fibre, Oakenfull \& Fenwick (1978) observed that the capacity of fibre sources to bind bile acids in vitro was dependent on the saponin content of the fibre source. Thus cereal fibres lacked the capacity to adsorb bile acids in vitro but acquired this capacity when supplemented with a saponin-rich ethanol-water extract of lucerne (Medicago sativa). The authors proposed that sources of dietary fibre rich in saponin would be more effective in reducing serum cholesterol by increasing faecal bile acid excretion. Whole soya beans contain $50-60 \mathrm{~g} / \mathrm{kg}$ dry weight as saponins and as such are an extremely rich source of these compounds. On that basis, Potter et al. (1979) proposed that the hypocholesterolaemia associated with soya-bean feeding in man (Sirtori et al. 1977) and rabbits (Carroll, 1978) was a function of the saponin in the soya-bean sources. This proposal was supported by the many observations that dietary saponins have the capacity to lower serum cholesterol in chickens, rats and pigs (Table 6).

The results of the present study with weanling rabbits do not agree with the saponin theory. The explanation may be in the method used to induce hypercholesterolaemia. In the present study it was achieved by feeding a cholesterol-free, low-fat diet based on animal protein, and as such it was a direct consequence of the balance of hepatic synthesis, catabolism and excretion of cholesterol. However, in all previous studies of the hypocholesterolaemic effect of plant saponins, the elevated levels of serum cholesterol were achieved by supplementing the diet with cholesterol, thus inducing an exogenously based hypercholesterolaemia, whereas that reported in the present study is endogenously based (Table 6). It could be argued, therefore, that the hypocholesterolaemia previously observed for saponins is due to the inhibition of cholesterol absorption (Malinow et al. 1979).

Several authors have reported increased excretion of acid and neutral sterols when saponin is added to the diets of rats (Oakenfull et al. 1979; Sautier et al. 1979) and pigs (Topping et al. 1980). However, in the present study, saponins appeared to be effective only when soya bean was used as the protein source. Since soya-bean feeding itself increases the intestinal pool and excretion of acid and neutral sterols, it is not surprising that when saponin is added to the diet there is further excretion of sterols, perhaps by inhibiting their reabsorption. This does not happen with milk-protein diets and there is no satisfactory explanation for this. 


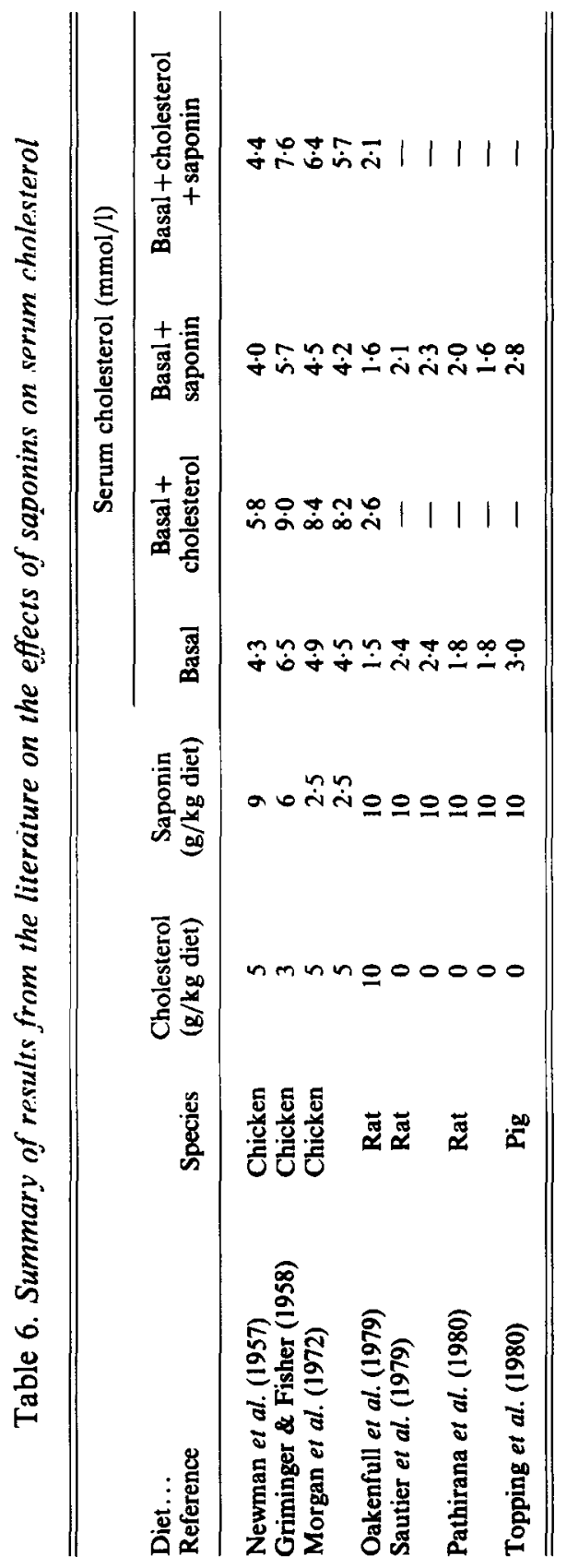



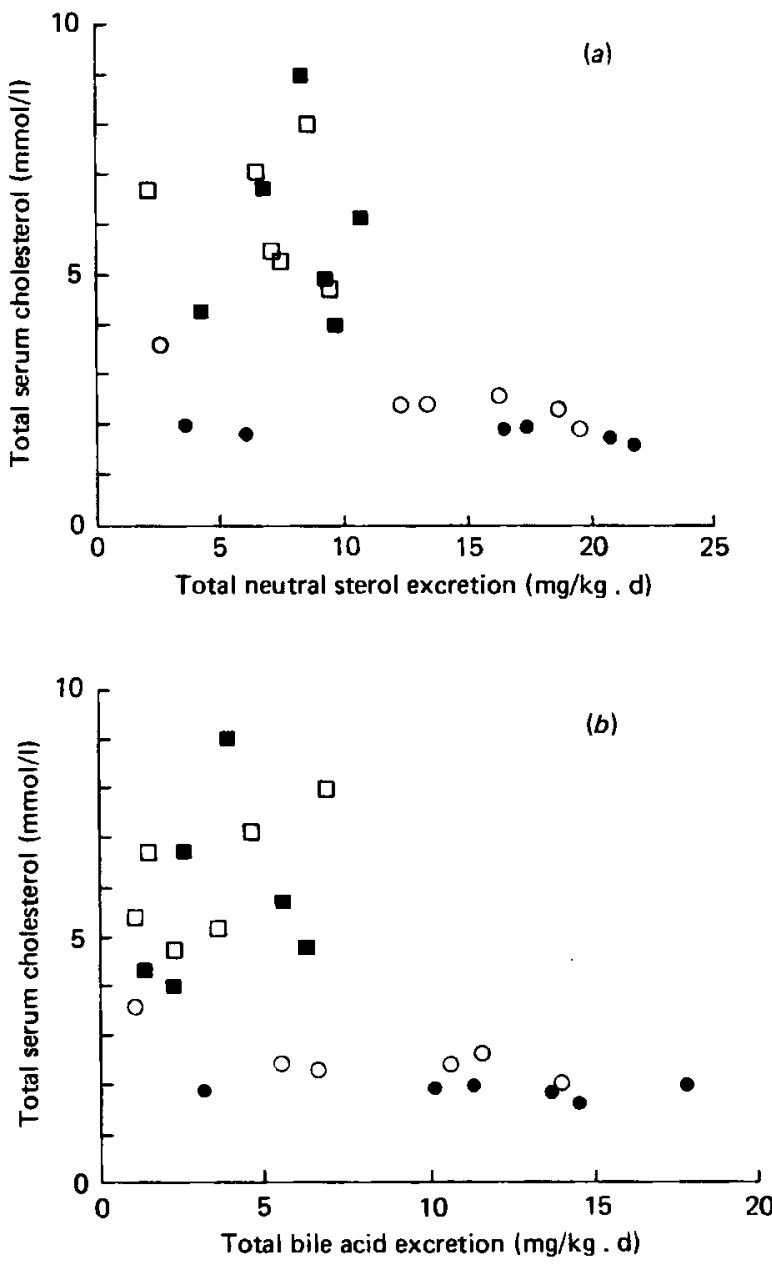

Fig. 1. The relationship between total serum cholesterol (mmol/l) and the excretion of $(a)$ neutral sterols and $(b)$ bile acids $(\mathrm{mg} / \mathrm{kg}$ per $\mathrm{d}$ ) in rabbits given different dietary protein sources with or without saponin. Cow's-milk diet without saponin ( $\square$ ); cow's-milk diet with $10 \mathrm{~g}$ saponin $/ \mathrm{kg}(\mathbf{\square})$; soya-bean-protein diet without saponin (O); soya-bean-protein diet with $10 \mathrm{~g}$ saponin $/ \mathrm{kg}(\mathbf{O})$.

Fig. 1 shows the excretion of acid and neutral sterols in relation to serum total cholesterol concentration, and it can be seen that the variation in serum cholesterol occurs over a narrow range of acid and neutral sterols. The converse is also true. Therefore, rabbits given milk protein may lack the capacity to maintain normal levels of serum cholesterol through impaired cholesterol oxidation. Results presented by Roberts et al. (1979) showed an increased turnover of plasma LDL cholesterol in rabbits given soya-bean protein. Alternatively, in milk-fed rabbits a normal biliary flow of bile acids and cholesterol may be associated with an enhanced capacity for reabsorption of endogenous sterols. Kim et al. (1980) found enhanced cholesterol absorption in casein-fed pigs. In rabbits, cholesterol absorption does not increase hepatic oxidation to bile acids of de novo synthesized cholesterol (Sabine, 1977).

The information on the excretion of individual acid and neutral sterols does not provide a basis for explaining the different effects of soya-bean and milk proteins on serum cholesterol. The substantial microflora of the rabbit caecum may have had an effect on the 
molar proportions of individual bile acids and neutral sterols, and thus it would not be possible to construct a hy pothesis like that recently put forward for the hypocholesterolaemic effect of dietary fibre in rats by Brydon et al. (1980).

There is growing evidence to suggest that the hypercholesterolaemic effect of casein and other purified animal proteins is due to the protein per se. Katan et al. (1980) and Hermus (1979) have shown that glycine supplementation of casein reduced serum cholesterol in rabbits and cholesterol-fed rats and was associated with reduced aortic atherosclerosis. Kritchevsky (1979) reported that supplementation of soya-bean protein with lysine so as to increase its lysine: arginine value to that in casein (from 0.9 to 2.0 ) resulted in a sharp increase in atherogenicity and serum cholesterol concentration. However, none of these authors has been able to explain the mode of action of amino acid supplementation on cholesterol metabolism. Noseda et al. (1980) have suggested the possible involvement of insulin and glucagon in the effect of protein on cholesterol metabolism, and this possibility merits serious consideration.

The influence of dieta:y protein on cholesterol metabolism has important implications for man, both in the treatrnent of hyperlipidaemia and in the interpretation of epidemiological results relating diet to the incidence of coronary heart disease. However, the information on the effect of protein source on plasma cholesterol in man is contradictory. Carroll et al. (1978) found a small but significant decrease in the plasma cholesterol of volunteers consuming a high soya-bean diet $(4.86-4.67 \mathrm{mmol} / 1$ plasma). Van Raaij et al. (1979), in a well-controlled study also using healthy normo-lipaemic volunteers, found that dietary protein source did not alter serum cholesterol, although when the same diets were fed to rabbits a dramatic increa.se was observed in the casein-fed group. Furthermore, Calvert et al. (1979) found that soya-bean-based cookies did not reduce serum cholesterol in normo-lipaemic volunteers, irrespective of the saponin content of the soya-bean supplement. Studies in this laboratory recorded a significant increase in the serum cholesterol concentration of healthy volunteers who modified their diet to provide $240 \mathrm{~g} / \mathrm{kg}$ protein intake from soya-bean (M. J. Gibney, unpublished results). However, a significant increase in fat intake may have confounded the results.

In contrast to these studies on normal healthy individuals, a series of studies by Sirtori et al. (1977; 1979), Karlstrom et al. (1979) and Descovich et al. (1979) on type II a and type II b hyperlipidaemic patients showed significant reductions in serum cholesterol concentration of the order of $10-20 \%$. Thus, the effect of dietary protein on serum cholesterol may be similar in normo-lipaemic man and the rat (Pathirana et al. 1980) whereas the situation in hyperlipaemic man may be more similar to that in rabbits.

Clearly, dietary protein can play an important role in cholesterol metabolism in many species including man and its mode of action warrants further study.

The receipt of a Commonwealth Tropical Medical Research Studentship is gratefully acknowledged by C.P. The authors acknowledge Portland Chemicals, Cardiff for a gift of dicalcium phosphate and Roche Products for gifts of vitamins A, D and E.

\section{REFERENCES}

Brydon, W. G., Radesse, K., ljastwood, M. A. \& Lawson, M. E. (1980). Br. J. Nutr. 43, 101.

Calvert, G. D., Blight, L. F., Topping, D. L., Yeates, R. A. \& Potter, J. D. (1979). Proc. Vth int. Symp. Atherosclerosis, Houston, Alsstr. 309.

Carroll, K. K. (1978). Lipids 13, 360.

Carroll, K. K., Giovanetti, P. JM., Huff, M.W., Moase, O., Roberts, D. C. K. \& Wolfe, B. M. (1978). Am. J. clin. Nutr. 31, 1312.

Danielson, H., Kallner, A. \& Sjorvall, J. (1963). J. biol. Chem. 238, 3846.

Descovitch, G. C., Ceredi, C, Benassi, M. S., Liverani, A., Vettori, A., Gaddi, A., Lenzi, S., Sirtori, M., Gatti, E., Mannino, G. \& Scaramuzzino, G. (1979). Proc. Vth int. Symp. Atherosclerosis, Houston, Abstr. 436. 
Griminger, P. \& Fisher, H. (1958). Proc. Soc. exp. Biol. Med. 99, 424.

Hellstrom, K., Sjovall, J. \& Wigand, G. (1962). J. Lipid Res. 3, 407.

Hermus, R. J. J. (1979). Proc. 3rd Eur. Nutr. Conf., Var Foda 31, Suppl. 181.

Karlstrom, B., Boberg, J., Gustaffson, I-B., Lithell, N., Versby, B. \& Werner, I. (1979). Proc. 3rd Eur. Nutr. Conf., Var Foda 31, Suppl. 188.

Katan, M. B., Vroomen, L. \& Hermus, R. J. J. (1980). Proc. VIlth int. Drug Symp., Drugs Affecting Lipid Metabolism, Milan, p. 104.

Kessler, G. \& Lederer, H. (1965). In Automation in Analytical Chemistry, p. 341 [L. T. Skeggs, editor]. New York: Mediaid Inc.

Kim, D. N., Lee, K. T., Reiner, J. T. \& Thomas, W. A. (1980). Proc. VIIth int Drug Symp., Drugs Affecting Lipid Metabolism, Milan, p. 273.

Kritchevsky, D. (1979). Lancet i, 610.

Malinow, M. R., McLaughlin, P., Stafford, C., Livingstone, A. L., Kohler, G. O. \& Cheeke, P. R. (1979). Am. J. clin. Nutr. 32, 1810.

Meeker, D. R. \& Kesten, H. D. (1940). Proc. Soc. exp. Biol. Med. 45, 543.

Morgan, B., Heald, M., Brooks, S. G., Tee, J. L. \& Green, J. (1972). Poultry Sci. 51, 677.

Newman, H. A., Kummerow, F. A. \& Scott, H. H. (1957). Poultry Sci. 37, 42.

Noseda, G., Fragiacomo, C., Descovich, G. C., Fumagelli, R., Bernini, F. \& Sirtori, C. R. (1980). Proc. VIIth int. Drug Symp., Drugs Affecting Lipid Metabolism, Milan, p. 275.

Oakenfull, D. G. \& Fenwick, D. E. (1978). Br. J. Nutr. 40, 299.

Oakenfull, D. G., Fenwick, D. E., Hood, R. L., Topping, D. L., Illman, R. L. \& Storer, G. B. (1979). Br. J. Nutr. 42, 209.

Pathirana, C., Gibney, M. J. \& Taylor, T. G. (1980). Atherosclerosis 36, 595.

Potter, J. D., Topping, D. L. \& Oakenfull, D. (1979). Lancet i, 223.

Roberts, D. C. K., Stalmach, M. E. \& Carroll, K. K. (1979). Proc. 3rd Eur. Nutr. Conf., Var Foda 31, Suppl. 247.

Sabine, J. R. (1977). Cholesterol. New York: Marcel Dekker.

Sautier, C., Doucet, C., Flament, C. \& Lemonnier, D. (1979). Atherosclerosis 34, 233.

Sirtori, C. R., Agradi, E., Conti, E., Mantero, O. \& Gatti, E. (1977). Lancet ii, 275.

Sirtori, C. R., Gatti, E., Mantero, O., Conti, F., Agradi, E., Tremoli, E., Sirtori, M., Fratterigo, L., Tarazzi, L. \& Kritchevsky, D. (1979). Am. J. clin. Nutr. 32, 1645.

Steel, R. G. D. \& Torrie, J. H. (1960). Principles and Procedures in Statistics. New York: McGraw-Hill.

Topping, D. L., Calvert, G. D., Storer, G. B., Illman, R. J., Oakenfull, D. G. \& Weller, R. A. (1980). Am. J. clin. Nutr. 33, 783.

Van Raaij, J. M. A., Katan, M. B. \& Hautvast, J. G. A. J. (1979). Lancet ii, 958.

Warnick, G. R. \& Albers, J. J. (1978). J. Lipid Res. 19, 65.

Wells, W. W. \& Makita, M. (1962). Analyt. Biochem. 4, 204. 